\title{
Review
}

\section{Homocysteine as a peripheral biomarker in bipolar disorder: A meta-analysis}

\author{
E. Salagre ${ }^{\mathrm{a}, \mathrm{b}, *}$, A.F. Vizuete ${ }^{\mathrm{c}}$, M. Leite $^{\mathrm{c}}$, D.J. Brownstein ${ }^{\mathrm{d}}$, A. McGuinness $^{\mathrm{a}}$, \\ F. Jacka ${ }^{a}$, S. Dodd ${ }^{\text {aee,k }}$, B. Stubbs ${ }^{\text {f,g,h,i }}$, C.A. Köhler ${ }^{j}$, E. Vieta ${ }^{\text {b }}$, A.F. Carvalho ${ }^{i}$, \\ M. Berk ${ }^{\mathrm{a}, \mathrm{e}, \mathrm{k}, \mathrm{l}}$, B.S. Fernandes ${ }^{\mathrm{a}, \mathrm{c}, * *}$ \\ a Deakin University, IMPACT Strategic Research Centre, School of Medicine, Barwon Health, Geelong, Australia \\ ${ }^{\mathrm{b}}$ Bipolar Unit, Hospital Clínic, University of Barcelona, IDIBAPS, CIBERSAM, Barcelona, Spain \\ ${ }^{\mathrm{c}}$ Laboratory of Calcium Binding Proteins in the Central Nervous System, Department of Biochemistry, Federal University of Rio Grande do Sul, Porto Alegre, \\ Brazil \\ ${ }^{\mathrm{d}}$ Monash University, Faculty of Medicine, Nursing and Health Sciences, Melbourne, Australia \\ e Department of Psychiatry, University of Melbourne, Parkville, Australia \\ ${ }^{\mathrm{f}}$ Health, Social Care and Education, Anglia Ruskin University, Chelmsford, UK \\ ${ }^{g}$ Geriatrics Division, Department of Medicine-DIMED, University of Padova, Padova, Italy \\ ${ }^{\mathrm{h}}$ Institute of clinical Research and Education in Medicine (IREM), Padova, Italy \\ i Physiotherapy Department, South London and Maudsley NHS Foundation Trust, Denmark Hill, SE5 8AZ London, UK \\ ${ }^{\mathrm{j}}$ Translational Psychiatry Research Group and Department of Clinical Medicine, Faculty of Medicine, Federal University of Ceará, Fortaleza, CE, Brazil \\ ${ }^{\mathrm{k}}$ Florey Institute for Neuroscience and Mental Health, University of Melbourne, Parkville, Australia \\ ${ }^{1}$ Orygen, The National Centre of Excellence in Youth Mental Health, University of Melbourne, Parkville, Australia
}

\section{A R T I C L E I N F O}

\section{Article history:}

Received 14 December 2016

Received in revised form 13 February 2017

Accepted 14 February 2017

Available online 1 March 2017

\section{Keywords:}

Precision psychiatry

Biomarker

Homocysteine

Bipolar disorder

Systematic review

Meta-analysis

\begin{abstract}
A B S T R A C T
Background: Bipolar disorder (BD) is a psychiatric disorder with an uncertain aetiology. Recently, special attention has been given to homocysteine (Hcy), as it has been suggested that alterations in 1-carbon metabolism might be implicated in diverse psychiatric disorders. However, there is uncertainty regarding possible alterations in peripheral Hcy levels in BD.

Methods: This study comprises a meta-analysis comparing serum and plasma Hcy levels in persons with $\mathrm{BD}$ and healthy controls. We conducted a systematic search for all eligible English and non-English peerreviewed articles.

Results: Nine cross-sectional studies were included in the meta-analyses, providing data on 1547 participants. Random-effects meta-analysis showed that serum and plasma levels of Hcy were increased in subjects with BD in either mania or euthymia when compared to healthy controls, with a large effect size in the mania group $(g=0.98,95 \% \mathrm{Cl}$ : $0.8-1.17, P<0.001, n=495)$ and a small effect in the euthymia group ( $g=0.3,95 \% \mathrm{CI}: 0.11-0.48, P=0.002, n=1052$ ).

Conclusions: Our meta-analysis provides evidence that Hcy levels are elevated in persons with BD during mania and euthymia. Peripheral Hcy could be considered as a potential biomarker in BD, both of trait (since it is increased in euthymia), and also of state (since its increase is more accentuated in mania). Longitudinal studies are needed to clarify the relationship between bipolar disorder and Hcy, as well as the usefulness of peripheral Hcy as both a trait and state biomarker in BD.
\end{abstract}

(c) 2017 Elsevier Masson SAS. All rights reserved.

\footnotetext{
* Corresponding author. Deakin University, School of Medicine, Barwon Health, Geelong, Victoria, Australia.

** Co-corresponding author. Bipolar Unit, Hospital Clínic, University of Barcelona, IDIBAPS, CIBERSAM, Barcelona, Spain.

E-mail addresses: esalagre@gmail.com (E. Salagre), brisasf@gmail.com (B.S. Fernandes).
}

\section{Introduction}

In order to better understand the physiopathology underlying bipolar disorder (BD), increasing research efforts have attempted to identify potential biomarkers in the peripheral blood of those with BD and also to advance the elusive field of precision psychiatry [1-4]. Neurotrophins such as BDNF [5-9] and inflammatory markers such as C-reactive protein [10-12] have 
consistently been proposed as promising peripheral biomarkers in $\mathrm{BD}$. More recently, special attention is being given to homocysteine (Hcy) [13], as it has been suggested that alterations in 1-carbon metabolism might be implicated in psychiatric disorders, including BD [14-17].

In the 1-carbon metabolism, a carbon unit from serine or glycine is transferred to tetrahydrofolate (THF) to form methyleneTHF. Homocysteine is a non-protein and nonessential amino acid sulfur with a central role in 1-carbon metabolism, and its regulation depends on multiple enzymes, with methylenetetrahydrofolate reductase (MTHFR) the most extensively investigated. Folate and vitamin B12 are also key elements of Hcy metabolism, since they act as enzymatic cofactors $[18,19]$. Accordingly, either a reduced enzymatic activity of MTHFR or a nutritional deficiency in folate or vitamin B12 may lead to hyperhomocysteinemia [19-21]. This may promote neurotoxic and vasculotoxic effects by several proposed mechanisms, including but not limited to mitochondrial dysfunction [22], oxidative stress induction [14,23,24], inflammation [25], neuroapoptosis [26,27], direct vascular damage [25,28], aberrant DNA methylation [29,30] and impaired DNA synthesis [31]. These pathways overlap considerably with those pathways documented as drivers of the process of neuroprogression evident in BD [32]. Equally, this is concordant with the notion of shared pathways to comorbidity of both psychiatric and common medical disorders [18,33].

Hyperhomocysteinemia is a known risk factor for cardiovascular diseases [34] and Alzheimer's dementia [35,36]. Additionally, several studies have described an association between higher levels of Hcy and depression [37-41], autism [42] and schizophrenia $[17,29,43]$. In addition, a recent meta-analysis by Numata et al. provided evidence that increased Hcy levels is causally related with an increased risk of developing schizophrenia using a Mendelian Randomization analysis [16]. In BD, higher levels of peripheral Hcy have been associated with worse cognitive performance $[44,45]$.

Contrary to schizophrenia, where better evidence exists, data on peripheral levels of Hcy in BD are more limited, with discrepant findings across studies conducted to date; some studies show increased levels of Hcy in persons with BD when compared to healthy controls [46], while others find no evidence for this association [47]. The aim of this study was therefore to verify if alterations in peripheral Hcy levels are present in BD in the different mood states compared to healthy controls. To this end, we performed a meta-analysis of all available cross-sectional studies that measured peripheral Hcy levels in BD compared to healthy subjects in order to evaluate the potential of Hcy as a biomarker in BD. The null hypothesis was that there would be no difference between individuals with BD compared to healthy controls.

\section{Methods}

We performed a meta-analysis comparing peripheral levels of Hcy in subjects with BD across different mood states versus healthy controls. We adhered to the Preferred Reporting Items for Systematic Reviews and Meta-Analyses (PRISMA) statement and guidelines from the Cochrane Collaboration [48]. The literature search, decisions on inclusion, data extraction and quality control were all independently performed by two of the authors (E.S., B.S.F.). Disagreements were resolved through consensus. An a priori defined but unpublished protocol was followed.

\subsection{Search strategy}

We conducted a systematic search for all potentially eligible peer-reviewed articles using PubMed and SCOPUS in January 2016. We included studies published in English, Dutch, French,
German, Italian, Portuguese and Spanish, with no year or country restrictions [48]. The Boolean terms used for the electronic database search were: (homocysteine or MTHFR or methylenetetrahydrofolate reductase or folate or folic acid or B12) and (bipolar or mania or psychosis). We manually searched bibliographies of the identified articles in order to identify further relevant references that might have been missed in the initial search. Study selection eligibility and exclusion criteria were pre-specified.

\subsection{Study selection}

We included studies meeting the following inclusion criteria:

- adult subjects with diagnosis of BD, as defined by Diagnostic and Statistical Manual of Mental Disorders (DSM), regardless of current mood state;

- pairwise comparison with a control group of healthy volunteers

- studies that assessed homocysteine levels in vivo.

\section{Exclusion criteria were:}

- duplicate reports;

- studies conducted in subjects aged less than 18 years;

- reviews or meta-analyses articles;

- lack of a control group of healthy volunteers;

- genetic studies not measuring Hcy levels;

- studies that included samples with mixed psychiatric diagnoses unless data for BD were reported separately or were obtained after contacting the authors;

- studies not specifying the mood state of the subjects at the time Hcy was assessed;

- studies which did not report data on subjects with BD separately according to mood state;

- animal studies.

We used the Newcastle-Ottawa Scale (NOS) for case-control studies [49] as recommended by the Cochrane Collaboration [50] to assess the quality of the eligible studies. Overall, quality score was defined as the frequency of criteria that were met by the particular study. The NOS scale contains eight items for assessing the quality of case-control studies, categorised into the three domains of selection, comparability, and exposure. A series of response options is provided for each item. A star system was used to enable semi-quantitative assessment of study quality, such that the highest quality studies are awarded a maximum of one star for each item, with the exception of the comparability domain, which allows the assignment of two stars. As such, the Newcastle-Ottawa scale ranges between zero and nine stars [49]. Item "non-response rate" from Exposure in the case-control scale was not applicable; therefore, a maximum of eight stars was considered. The quality score of the included was four and five. All studies were included in the posterior analyses.

\subsection{Data extraction}

Two independent reviewers extracted data $[n$, mean and standard deviation (SD)] using a predesigned form [48]. Whenever necessary, authors of included studies were electronically contacted to provide data in at least two separate occasions. Whenever data on the same participants were provided by different articles, only the most comprehensive data set was included. When necessary, means and SD were calculated from available graphs using procedures described in details elsewhere [51].

All variables were extracted separately for each mood state (euthymia, mania or depression). We extracted the following data: sample size, age, sex, length of illness in years, body mass index 
(BMI), smoking status, mean score of the Hamilton Depression Rating Scale (HDRS) [52] and the Young Mania Rating Scale (YMRS) [53], medications in use, study population, type of assay, and sampling source (plasma or serum).

\subsection{Publication bias}

Studies with negative (i.e., non-significant) results are less likely to be published than studies with positive (i.e., statistically significant) results. To account for potential publication bias, an acknowledged problem in the field of peripheral biomarkers in psychiatric disorders including BD and major depressive disorder $[54,55]$, we inspected funnel plot graphs, which are scatter plots of the effect size (ES) against a measure of study sample size, and the Egger's regression test [56]. In addition, the Orwin's fail-safe N test (file drawer statistic) was used to quantify the number of possible negative omitted studies that would be required to render statistically significant results non-significant (i.e., $P>0.05$ ) [57].

\subsection{Statistical analysis}

Our primary aim was to quantify differences in peripheral Hcy levels in persons with BD compared to healthy volunteers. We employed Comprehensive Meta-Analysis Software (CMA) version 2.0 in all analyses. Since eligible studies included different assay methods, we used standardized mean differences to estimate differences in peripheral Hcy levels in individuals with BD compared to healthy controls. We used Hedges' adjusted $g$, as it provides a relatively unbiased ES estimate adjusted for sample size. We also calculated the $95 \%$ confidence interval $(95 \% \mathrm{CI})$ of the ES. An ES of 0.2 was considered as a small ES, i.e., it indicates a small difference in Hcy levels between subjects with BD and controls, while an ES of 0.5 was considered as a moderate effect and an ES $\geq 0.8$ as a large effect [58]. The direction of the ES values was negative if subjects with BD showed decreased Hcy levels when compared to healthy controls, and positive if they showed increased Hcy levels.

Heterogeneity across studies was assessed using the Cochran Q test, a weighted sum of the squares of the deviations of individual study ES estimates from the summary ES estimate, and a $P$ value of $<0.10$ was considered significant (i.e., indicating heterogeneity). Inconsistency across studies was also evaluated using the $\mathrm{I}^{2}$ metric, which describes the percentage of the variability in effect estimates that is due to heterogeneity rather than sampling error. An $\mathrm{I}^{2}>50 \%$ is considered indicative of substantial heterogeneity [48].

Both measures of heterogeneity (i.e., the Cochran Q test and the $\mathrm{I}^{2}$ metric) have a limited power to detect heterogeneity unless very large data sets are available. Thus, we pooled ES estimates of individual studies using random-effects modelling, which allows population-level inferences and is more stringent than fixedeffects models. Random-effects models assume that the true effect size differs across studies and incorporates a between-study variance into the calculations [48,59].

Unrestricted maximum likelihood random-effects meta-regressions of ES were performed in euthymic subjects, with mean age and percentage of female sex as moderators, to determine whether these covariates influenced the ES. Meta-regression analyses with data from fewer than five datasets may provide spurious findings [48]. Therefore, we explored potential sources of heterogeneity with this tool only when independent data from at least five studies were available. Studies were weighted such that the studies with the most precise parameters, quantified by the sample size and $95 \% \mathrm{CI}$, had more influence in the regression analyses.

The meta-analyses consisted of three steps. Firstly, we performed the meta-analyses according to mood state. As only a single study assessing Hcy levels in BD subjects with a depressive episode was identified [60], we limited our analyses to mania and euthymia. Secondly, sensitivity analyses were conducted to ascertain whether the results of our analyses were strongly influenced by any single study or studies sharing some characteristics. The overall significance was recomputed after each study or group of studies with a common feature were deleted from the analysis. Thirdly, we performed meta-regression analyses in order to investigate possible moderators of Hcy levels. The level of significance was set at $P<0.05$.

\section{Results}

\subsection{Selection and inclusion of studies}

In total, 2597 studies were identified through the systematic electronic search. Of those, we excluded 2540 on the basis of title and abstract. We went through 57 full-text articles of which: two were excluded because they were duplicates of included studies with overlapping samples [61,62]; eighteen studies were excluded because they lacked a control group [38,46,63-78]; twelve were excluded because they were not performed in subjects with a diagnosis of BD [41,79-89]; twelve were excluded because they did not measure Hcy levels [90-101]; and two were excluded because they presented mixed data on BD and other psychiatric disorders [102,103]. The authors of a study that analysed together the total mean Hcy level for subjects with BD in different mood states were contacted to request mean Hcy levels separately according to mood states. Since no response was provided, this article was also excluded [104]. In total, we identified 10 studies fulfilling our inclusion criteria, of which two studies measured Hcy levels in mania ( 227 persons with BD and 268 healthy controls) $[105,106]$, eight in euthymia (436 persons with BD and 616 healthy controls) [44,106-112] and one in depression [60] (Fig. 1). As there was only one article assessing Hcy levels in persons with BD in depression, which found no differences in Hcy levels between persons with BD and the control group [60], a meta-analysis could not be conducted. All studies included in the analyses were crosssectional and they provided data on 1547 participants; of these, 663 comprised subjects with BD and 884 were healthy controls. One study [106] provided more than one pairwise comparison.

\subsection{Study characteristics}

The characteristics of the included studies are summarized in Table 1. The studies were published from 2004 to 2013. They included participants of either sex with a mean age between 33.6 and 49.8. The diagnosis of bipolar disorder was made according to the DSM-IV. Severity of affective symptoms was assessed with the YMRS for manic symptoms and the HDRS for depressive symptoms. Only one study provided data on YMRS in the mania group [106] and the median score was 27.5 (19-30.7). The euthymia group was defined as scoring less than 6 on the YMRS and less than 8 on the HDRS across studies.

In six of the nine studies, the control group was matched by sex and age [90,106-108,111,112]. All subjects with BD were on psychopharmacological treatment. Seven studies provided details on the medications used [105,107-112], the most common being mood stabilizers, antidepressants, and first and second generation antipsychotics. All studies excluded subjects with either long-term somatic conditions or substance use disorders.

\subsection{Hcy levels are increased in $B D$ compared to healthy controls}

We included two studies in the meta-analysis of Hcy levels in subjects with BD in manic state compared with healthy controls $[105,106]$ and eight studies in the meta-analysis that compared subjects with $\mathrm{BD}$ in euthymic state compared with healthy 


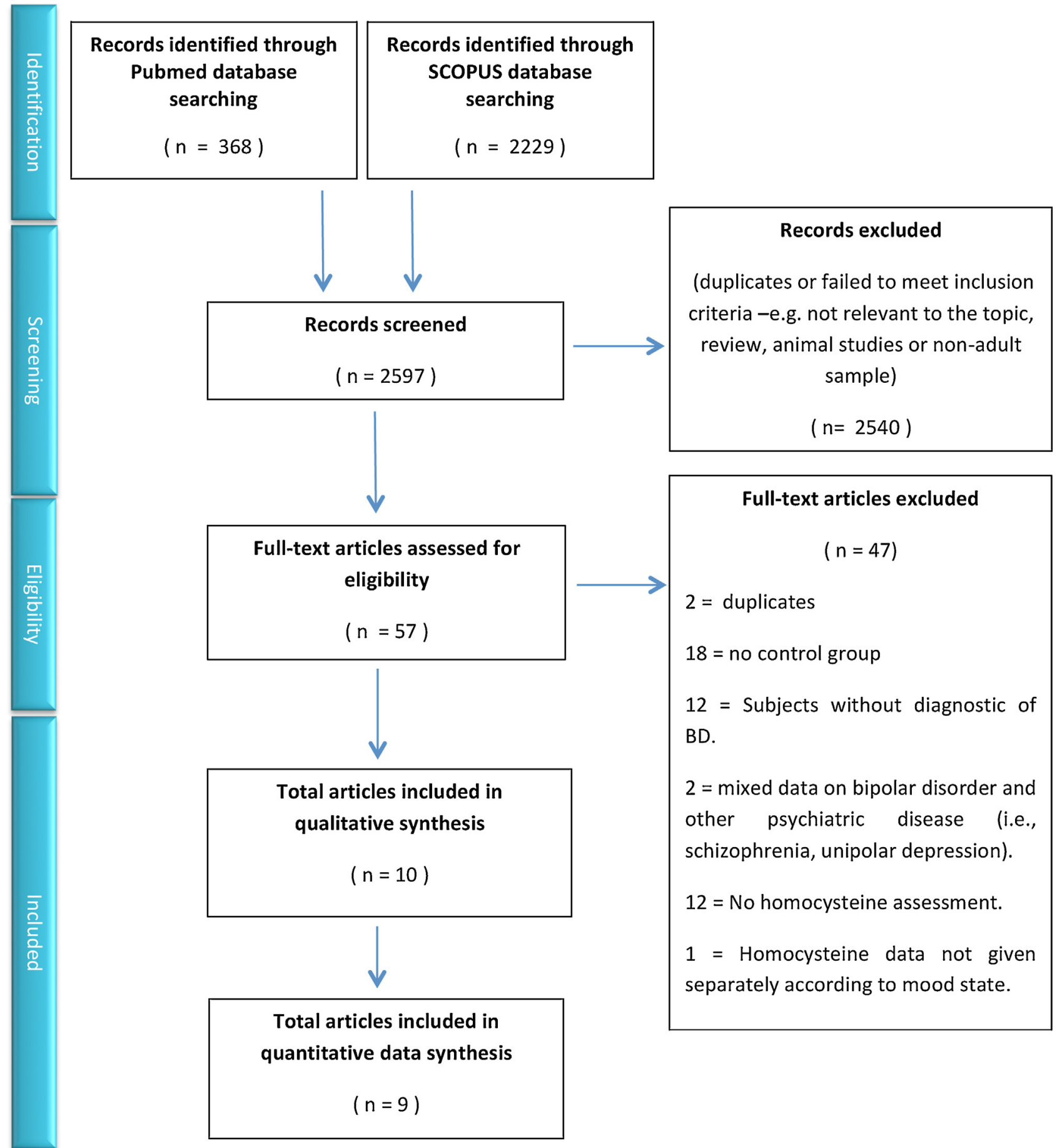

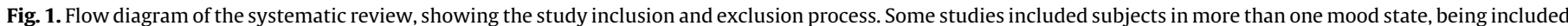
in more than one analysis.

controls [44,106-112]. Random-effects meta-analysis showed that serum and plasma levels of Hcy were increased in subjects with BD either in mania or in euthymia when compared to healthy controls, with a large effect in the mania group ( $g=0.98,95 \% \mathrm{CI}$ : $0.80-1.17$, $P<0.001,2$ between-group comparisons, $n=495$ ) and a small effect in the euthymia group $(g=0.30,95 \% \mathrm{CI}: 0.11-0.48, P=0.002$, 8 between-group comparisons, $n=1052$ ) (Fig. 2, Table 2).

\subsection{Hcy levels in $B D$ are not associated with age or sex}

We performed meta-regression analyses to identify possible effect moderators. Since there were a small number of studies assessing Hcy in mania, we only performed the meta-regression analyses for the euthymia group. In univariable meta-regression models for euthymia, we found that neither age (slope $=-0.01,95 \%$ CI: -0.04 to $0.03, P=0.711$ ) nor sex (slope $=0.001,95 \% \mathrm{CI}:-0.02$ to $0.02, P=0.943$ ) were related to the difference in Hcy levels in euthymia between those with BD and controls (Table 2).

\subsection{Sensitivity analyses and publication bias}

We found no heterogeneity between studies performed in persons with $\mathrm{BD}$ in manic state $\left(\mathrm{I}^{2}=0 \%, P=0.39\right)$. In contrast, heterogeneity was moderate between studies performed in 
Table 1

Demographic characteristics of studies included in the meta-analysis of serum or plasma homocysteine (Hcy) levels in bipolar disorder.

\begin{tabular}{|c|c|c|c|c|c|c|c|c|c|}
\hline Study & $\begin{array}{l}\text { State and subjects } \\
\text { characteristics }\end{array}$ & $n$ (male/female) & $\mathrm{Age}^{\mathrm{a}}$ & $\mathrm{YMRS}^{\mathrm{a}}$ (SD) & $\operatorname{HDRS}^{\mathrm{a}}(\mathrm{SD})$ & $\begin{array}{l}\text { Length of } \\
\text { illness (years) }\end{array}$ & Source and assay & $\begin{array}{l}\text { Comorbidities and exclusion } \\
\text { criteria }\end{array}$ & Medication \\
\hline \multirow[t]{2}{*}{$\begin{array}{l}\text { Osher et al., } \\
2004\end{array}$} & $\begin{array}{l}\text { Euthymia } \\
\text { Outpatients, } \\
\text { euthymic for } \\
\geq 1 \text { month }\end{array}$ & $41(23 / 18)$ & 49.8 & NA & NA & NA & $\begin{array}{l}\text { Serum, high-pressure liquid } \\
\text { chromatography (HPLC) with } \\
\text { fluorescence detection }\end{array}$ & $\begin{array}{l}\text { Patients with diabetes, } \\
\text { cardiovascular disease, renal } \\
\text { disease, endocrinological disease, } \\
\text { neurological disease or substance } \\
\text { abuse were excluded }\end{array}$ & $\begin{array}{l}\text { Lithium carbonate; Valproic acid; } \\
\text { Carbamazepine, antipsychotics and } \\
\text { antidepressants }\end{array}$ \\
\hline & Control & $305(151 / 154)$ & 49.7 & & & & $\begin{array}{l}\text { Plasma, HPLC with fluorescence } \\
\text { detection }\end{array}$ & & \\
\hline \multirow[t]{2}{*}{$\begin{array}{l}\text { Osher et al., } \\
2008\end{array}$} & $\begin{array}{l}\text { Euthymia } \\
\text { Outpatients, } \\
\text { euthymic for } \\
\geq 1 \text { month }\end{array}$ & $57(35 / 22)$ & 39.4 & $<5$ & $<7$ & $13.54($ SD 10.3) & $\begin{array}{l}\text { Serum, HPLC with fluorescence } \\
\text { detection }\end{array}$ & $\begin{array}{l}\text { Patients with any serious physical } \\
\text { illness or substance abuse were } \\
\text { excluded }\end{array}$ & $\begin{array}{l}\text { Lithium carbonate; Valproic acid; } \\
\text { Carbamazepine, typical or atypical } \\
\text { antipsychotics and antidepressants }\end{array}$ \\
\hline & Control & $84(41 / 43)$ & 43.6 & & & & $\begin{array}{l}\text { Plasma, HPLC with fluorescence } \\
\text { detection }\end{array}$ & & \\
\hline \multirow[t]{2}{*}{$\begin{array}{l}\text { Ozbeck et al., } \\
2008\end{array}$} & $\begin{array}{l}\text { Mania } \\
\text { Inpatients }\end{array}$ & $197(74 / 123)$ & 40.5 & NA & $\mathrm{NA}$ & NA & $\begin{array}{l}\text { Serum, Fluorescence Polarization } \\
\text { Immunoassay (FPIA) }\end{array}$ & $\begin{array}{l}\text { Patients with neurological } \\
\text { comorbidity, mental retardation, } \\
\text { substance abuse, family or personal } \\
\text { history of cardiovascular disease, } \\
\text { endocrinological and metabolic } \\
\text { disease were excluded }\end{array}$ & $\begin{array}{l}\text { Typical and atypical antipsychotics } \\
\text { or combination }\end{array}$ \\
\hline & Control & $238(67 / 171)$ & 41.3 & & & & & & \\
\hline \multirow[t]{2}{*}{$\begin{array}{l}\text { Dittman et al., } \\
2008\end{array}$} & $\begin{array}{l}\text { Euthymia } \\
\text { Outpatient in } \\
\text { euthymia for } \\
\geq 1 \text { month on a } \\
\text { stable treatment }\end{array}$ & $74(37 / 37)$ & 42.5 & $1.01(1.45)$ & $1.36(1.56)$ & 16.7 (SD 10.6) & $\begin{array}{l}\text { Plasma, HPLC with fluorescence } \\
\text { detection }\end{array}$ & $\begin{array}{l}\text { Patients with severe physical or } \\
\text { neurological illnesses, present } \\
\text { substance abuse, } \\
\text { neurodegenerative disorders, } \\
\text { mental retardation were excluded }\end{array}$ & $\begin{array}{l}\text { Lithium carbonate; Valproic acid; } \\
\text { lamotrigine; Oxcarbazepine; } \\
\text { typical and atypical antipsychotic; } \\
\text { antidepressant }\end{array}$ \\
\hline & Control & $42(20 / 22)$ & 43 & $0.10(0.37)$ & $0.19(0.5)$ & & $\begin{array}{l}\text { Plasma, HPLC with fluorescence } \\
\text { detection }\end{array}$ & & \\
\hline \multirow[t]{2}{*}{$\begin{array}{l}\text { Bromberg et al., } \\
2009\end{array}$} & Euthymia & $49(29 / 20)$ & 39 & NA & NA & $\begin{array}{l}14.41(\mathrm{SD} \\
11.12)\end{array}$ & $\begin{array}{l}\text { Plasma, HPLC with fluorescence } \\
\text { detection }\end{array}$ & $\begin{array}{l}\text { Subjects with Alzheimer's disease, } \\
\text { diabetes, cardiovascular disease or } \\
\text { renal failure were excluded }\end{array}$ & $\begin{array}{l}\text { Lithium carbonate; Valproic acid; } \\
\text { other mood stabilizers }\end{array}$ \\
\hline & Control & $27(17 / 10)$ & 41.6 & & & & $\begin{array}{l}\text { Plasma, HPLC with fluorescence } \\
\text { detection }\end{array}$ & & \\
\hline \multirow[t]{2}{*}{ Dias et al., 2009} & $\begin{array}{l}\text { Euthymia } \\
\text { Outpatients in } \\
\text { euthymia for } \\
\geq 1 \text { month }\end{array}$ & $65(24 / 41)$ & 37.8 & $1(1.72)$ & $2.6(2.36)$ & $13.3(\mathrm{SD} 8.78)$ & $\begin{array}{l}\text { Serum, HPLC with fluorescence } \\
\text { detection }\end{array}$ & $\begin{array}{l}\text { Patients with neurological } \\
\text { disorders, head trauma, significant } \\
\text { physical illnesses, substance abuse } \\
\text { or ETC in the preceding } 6 \text { months } \\
\text { were excluded }\end{array}$ & $\begin{array}{l}\text { Patients under medication, } \\
\text { treatment not detailed }\end{array}$ \\
\hline & Control & $49(14 / 35)$ & 33.6 & $0.1(0.28)$ & $0.7(1.28)$ & & $\begin{array}{l}\text { Serum, HPLC with fluorescence } \\
\text { detection }\end{array}$ & & \\
\hline \multirow[t]{2}{*}{$\begin{array}{l}\text { Doğanavşargil- } \\
\text { Baysal et al., } \\
2013\end{array}$} & $\begin{array}{l}\text { Euthymia } \\
\text { Outpatients }\end{array}$ & 60 (NA) & NA & $0.1(0.54)$ & $0.75(1.14)$ & $12.13(\mathrm{SD} 8.9)$ & Serum & $\begin{array}{l}\text { Patients with neurological diseases, } \\
\text { cardiovascular diseases, renal or } \\
\text { hepatic diseases, diabetes mellitus, } \\
\text { hypo/hyperthyroidism, non- } \\
\text { psychotropic drug use that could } \\
\text { affect Hcy levels, substance abuse, } \\
\text { IQ }<80 \text { or ETC in the preceding } \\
6 \text { months were excluded }\end{array}$ & $\begin{array}{l}\text { Lithium carbonate; Valproic acid; } \\
\text { neuroleptics }\end{array}$ \\
\hline & Control & $20(\mathrm{NA})$ & NA & & & & & & \\
\hline
\end{tabular}




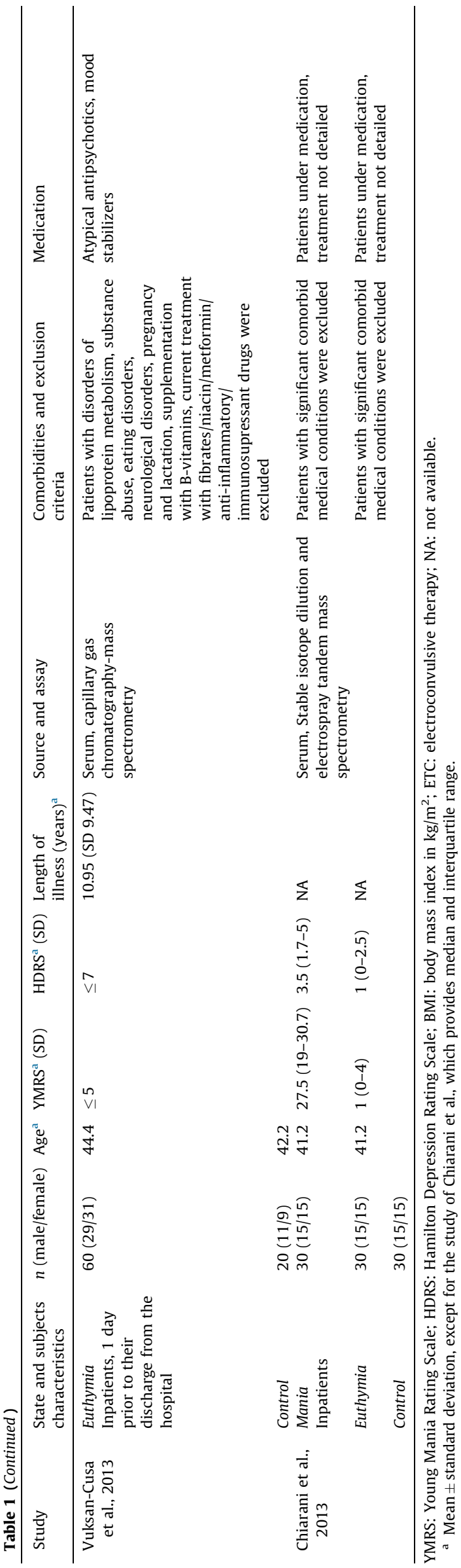

euthymia $\left(I^{2}=43.3 \%, P=0.09\right)$. To examine potential sources of heterogeneity detected in the euthymia group, we conducted sensitivity analysis. We excluded studies one at a time, in order to define its individual influence on the estimated overall effect and, therefore, determine the robustness of the analyses, and we did not find any particular study being responsible for heterogeneity in the euthymia group.

In addition, we found no evidence of publication bias on the funnel plot. The trim-and-fill estimate did not suggest any missing studies and the Orwin's fail-safe $\mathrm{N}$ test suggested that 148 negative missing studies would be necessary to turn our statistically significant results non-significant [57].

\section{Discussion}

\subsection{Summary of main findings}

Our results indicate that higher Hcy levels are found in persons with BD in manic and euthymic states when compared to healthy controls. The meta-regression analyses performed in the euthymia group showed that these differences were not significantly moderated by age or sex. This is the first meta-analysis to assess peripheral Hcy as a putative biomarker in BD.

\subsection{Implications}

Although there is growing literature showing an association between increased Hcy levels and psychiatric disorders, the nature of this relationship remains unclear. The role of Hcy in the Central Nervous System (CNS) is complex, as it participates in a large number of processes. It has been proposed that an alteration in glutamatergic neurotransmission may be a main mechanism linking Hcy and psychiatric disorders, including BD [19,113]. Homocysteine and its related compounds may have a role as a partial excitatory agonist on the N-Methyl-D-aspartate (NMDA) subtype of glutamate receptors and also on modulatory sites. Thus, longterm activation of NMDA receptors due to hyperhomocysteinemia would result in an increased calcium ion influx, elevated intracellular second messenger calcium, and accumulation of reactive oxygen species and, ultimately, would lead to cell damage and induction of both apoptotic and necrotic cell death $[19,26,114]$. Higher Hcy levels induced by methylenetetrahydrofolate reductase deficiency alters glutamatergic and GABAergic levels and contributes to neurotoxicity in the CNS [115].

It has also been hypothesized that long exposure to excessive levels of Hcy in the CNS can activate inflammatory pathways involving oxidative stress and pro-inflammatory cytokines, producing neural toxicity and microvascular damage $[20,47,116,117]$. Moreover, the brain depends on the 1-carbon metabolism to obtain methyl groups, with homocysteine acting as a methyl donor through its transformation to S-adenosylmethionine (SAMs), which is the main methyl donor in the CNS $[18,31]$. Hence, dysregulation of the 1 -carbon metabolism may promote aberrant DNA methylation, which has as well been proposed as a potential mechanism involved in the development of psychiatric illnesses, including BD [107,118-123]. Finally, the 1carbon metabolism also participates in monoamine regulation, so alterations in Hcy metabolism could lead to inadequate monoamine production and, consequently to dysregulation of serotonin, norepinephrine and dopamine [31,47]. Hyperhomocysteinemia may interfere with cholinergic metabolism by reducing choline acetyltransferase activity in some neuronal populations potentially leading to cognitive effects [124]. Cognitive impairment is a key factor involved in psychosocial functioning [125], so the relevance of homocysteine in BD may go beyond its potential use as another 


\begin{tabular}{|c|c|}
\hline & Study \\
\hline 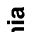 & Ozbek et al., 2008 \\
\hline$\sum^{\frac{\pi}{\pi}}$ & Chiarani et al., 2013a \\
\hline & Osher et al., 2004 \\
\hline & Dittman et al., 2008 \\
\hline & Osher et al., 2008 \\
\hline & Bromberg et al., 2009 \\
\hline & Dias et al., 2009 \\
\hline & Doganavsargil-Baysal et al., 2013 \\
\hline & Vuksan-Cusa et al., 2013 \\
\hline & Chiarani et al., 2013b \\
\hline
\end{tabular}

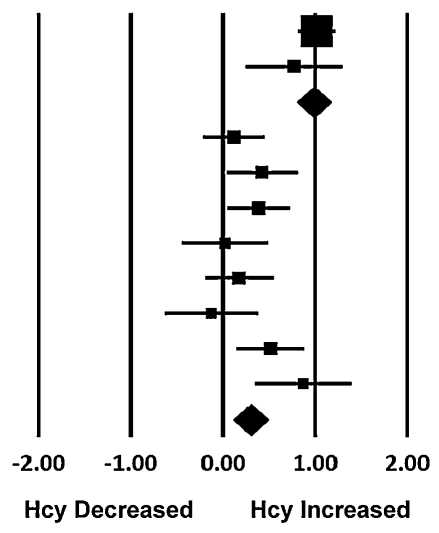

Fig. 2. Forest plot for random-effects meta-analysis on serum and plasma homocysteine levels in persons with bipolar disorder compared to healthy controls.

Table 2

Statistics on between-group meta-analysis regarding serum and plasma Hcy levels in bipolar disorder.

\begin{tabular}{|c|c|c|c|c|c|c|c|c|c|}
\hline \multirow{2}{*}{$\begin{array}{l}\text { Group-wise } \\
\text { State }\end{array}$} & \multirow[t]{2}{*}{ No. of pairwise } & \multicolumn{2}{|c|}{ No. of subjects } & \multicolumn{3}{|c|}{ Meta-analysis } & \multicolumn{3}{|c|}{ Heterogeneity } \\
\hline & & $\mathrm{BD}$ & $\mathrm{HC}$ & Hedges' $g$ & $95 \% \mathrm{CI}$ & $P$ & $I^{2}$ & Q & $P$ \\
\hline Mania vs. HC & 2 & 227 & 268 & 0.98 & $0.80-1.17$ & $<0.001$ & 0.00 & 0.75 & 0.388 \\
\hline Euthymia vs. HC & 8 & 436 & 616 & 0.30 & $0.11-0.48$ & 0.002 & 43.32 & 12.35 & 0.09 \\
\hline \multirow[t]{2}{*}{ Moderator } & \multirow[t]{2}{*}{ No. of pairwise } & \multicolumn{2}{|c|}{ No. of subjects } & \multicolumn{3}{|c|}{ Meta-regression } & \multicolumn{3}{|c|}{ Meta-regression } \\
\hline & & $\mathrm{BD}$ & $\mathrm{HC}$ & Slope & $95 \% \mathrm{CI}$ & $P$ & Intercept & $Z$ & $P$ \\
\hline Age - euthymia & 7 & 376 & 596 & -0.01 & -0.04 to 0.03 & 0.104 & 0.62 & 0.79 & 0.427 \\
\hline$\%$ Female - euthymia & 7 & 376 & 596 & 0.01 & -0.02 to 0.02 & 0.943 & 0.3 & 0.61 & 0.544 \\
\hline
\end{tabular}

BD: bipolar disorder; HC: healthy controls.

peripheral biomarker but also as a tentative biomarker of prognosis pertaining neuroprogression. That would certainly need further longitudinal studies. The association between homocysteine levels and cognitive problems suggests that pharmacological interventions capable of decreasing Hcy levels could be beneficial in BD and, perhaps conversely, interventions that proved effective in functional and cognitive decline might decrease hyperhomocysteinemia [126,127]. Folate and vitamin B12 are key elements of Hcy metabolism, since they act as enzymatic cofactors that decrease Hcy production, with folate and vitamin B12 being cofactors for the methylation of Hcy into methionine and tetrahydrofolate (THF), which is the immediate acceptor of 1carbon units for the synthesis of thymidine, purines (RNA and DNA), and methionine $[18,19]$. However, the benefit of prescribing folate to patients with depression without folate deficiency is controversial. One clinical trial found that folate supplementation using folic acid, the most commonly employed form of pharmacological supplementation, did not decrease the occurrence of depression in young people with increased risk of mood disorders, although it delayed the occurrence of the first episode of depression [128], and a clinical trial with 475 persons with an acute unipolar major depressive episode without vitamin deficiencies showed no benefit with folate [129]. A recent metaanalysis confirmed no short-term benefit of folate or B12 supplementation for depression, although there was a suggestion of a possible long-term benefit to prevent incidence or relapse [130].

However, this lack of effect might be due to the fact that the blood-brain barrier (BBB) is relatively impermeable to folic acid and folate, therefore the effect of supplementation with folic acid might only appear after several months, with a slow and cumulative effect of folate [131]; it has been hypothesised that probably methylfolate, the biologically active form of folate that can freely cross the BBB and cell membranes and that is also the predominant form of folate acquired through diet, would be a better choice as a pharmacological treatment. In addition, folic acid, the synthetic form of folate employed in abovementioned studies, needs to undergo enzymatic reduction by the enzyme dihydrofolate reductase (DHFR) in order to become biologically active within the cell [132]. Also, one clinical trial suggested that folic acid could significantly reduce the effect of lamotrigine in bipolar depression [133]. Consequently, methylfolate may be associated with a reduced interaction with drugs that inhibit dihydrofolate reductase, such as is the case with lamotrigine, than folic acid [132].

It is possible that the direction of the association between BD and Hcy is reversed, meaning that BD leads to increased Hcy levels, and not the opposite. It is also possible that confounders associated with both BD and Hcy play a role in the findings of increased Hcy levels in BD. Most likely, the reality is a combination of these three scenarios. It is also worth noting that low levels of physical activity are associated with elevated Hcy levels [134], and persons with BD are known to be more sedentary than healthy controls [135]. Exercise interventions, particularly resistance exercise, can reduce Hcy levels [136], and future research may wish to consider if exercise can reduce Hcy levels, cardiovascular risk and improve other health parameters in people with BD [137].

Although older age has been linked to higher levels of Hcy, for instance, due to dietary factors $[21,114,138]$, our meta-regression analyses found no relationship between age and Hcy levels in persons with BD in euthymia. This might suggest that higher levels of Hcy may be present since the beginning of the illness at a younger age in $\mathrm{BD}$, independently of environmental factors. This is in line with the results of Misiak et al., who found that Hcy plasma levels were significantly higher in first episode schizophrenia patients than in healthy controls [139]. Likewise, higher levels of 
Hcy have been described in males compared to females with BD [75], which suggests a potentially protective role of estrogens amongst many other biological and social factors [140]. Nevertheless, sex did not emerge as a significant moderator in our metaregression analyses.

Finally, the new field of research focused on the microbiomegut-brain axis in psychiatry may be of relevance [141]. Gut microbiota synthesise B-group Vitamins [142] and maladaptive metabolism of these vitamins may be a function of microbiota dysbiosis, which in turn may be both cause and consequence of mood disorders [143]. As this field develops, more insights into the possible mechanistic pathways between microbes and the brain will possibly emerge; given the modifiable nature of the gut microbiota, this may yield new targets for intervention [144].

\section{Strengths and limitations}

Our study has some strengths and limitations that deserve discussion. Firstly, we included a relatively small number of studies with a cross-sectional design, which does not allow inferring of causality, besides having other potential limitations such as confounding and selection bias. However, we found no evidence of heterogeneity across studies performed in persons with BD in mania and moderate heterogeneity between studies performed in euthymia. A strength of this meta-analysis is that we found no evidence of publication bias, a common issue with biomarkers in psychiatric disorders such as BD [55] and major depressive disorder [54], as the funnel plot was symmetric. In addition, we estimated that 148 missing studies with null results would be necessary to turn our significant results into negative ones. In addition, due to the small number of available studies we were not able to analyse the relationship between depressive symptoms and Hcy as we only identify one article assessing this issue. Similarly, the limited number of identified studies for mania prevented us from conducting meta-regressions analysing possible associations between sex, age and Hcy levels in this subgroup. Another point is that Hcy levels are known to be influenced by several factors, including physical activity, numerous systemic illnesses, diet (especially vitamin B12 and folic acid levels), BMI, and smoking. As only a minority of studies provided data on these factors, we were not able to perform meta-regression analyses using them as moderators. Importantly, Hcy levels are also influenced by medications such as lamotrigine or valproate [20] and all the included patients were on pharmacological treatment. Fourthly, all studies determined Hcy levels in the periphery, but as it is known that Hcy metabolism pathways differ between the CNS and the periphery $[145,146]$, it is not sure that peripheral Hcy levels are representative of central Hcy levels. Data on key genotype variants would also have been informative if available. It would similarly be valuable to have longitudinal data to determine if Hcy is a biomarker of trait or state in from a pathophysiological perspective, and if it also could be a biomarker with clinical value as a biomarker of response to treatment and/or prognosis, given that it will have adequate sensitivity and specificity [147,148].

\section{Conclusions}

Our meta-analysis provides evidence that Hcy levels are elevated in persons with BD in mania or euthymia independently of sex and age. These findings provide preliminary evidence that peripheral Hcy levels could be a potential biomarker in BD, both of trait (since it is increased in euthymia), and also of state (since its increase is more accentuated in mania). Larger longitudinal studies taking into account the confounding effect of the aforementioned variables and assessing patients in the different mood states are needed to clarify the relationship between bipolar disorder and Hcy as well as the clinical usefulness of peripheral Hcy as a biomarker for diagnosis, of response to treatment and/or prognosis.

\section{Funding body agreements and policies}

B.S.F. is supported by a postdoctoral fellowship from Deakin University, Australia. CAK is supported by a postdoctoral scholarship from the Coordenação de Aperfeiçoamento de Pessoal de Nível Superior (CAPES; Brazil). A.F.C. is supported by a research fellowship award from the Conselho Nacional de Desenvolvimento Científico e Tecnológico (CNPq; Brazil). M.B. is supported by a NHMRC Senior Principal Research Fellowship 1059660.

E.V. is grateful to Instituto de Salud Carlos III, Spanish Ministry of Economy and Competiveness, (PI 12/00912) integrated into the Plan Nacional de I + D + I and cofounded by ISCIII-Subdirección General de Evaluación and el Fondo Europeo de Desarrollo Regional (FEDER); Centro para la Investigación Biomédica en Red de Salud Mental (CIBERSAM), Secretaria d'Universitats i Recerca del Departament d'Economia i Coneixement (2014_SGR_398), Seventh European Framework Programme (ENBREC), CERCA Programme/Generalitat de Catalunya and the Stanley Medical Research Institute for their support.

\section{Disclosure of interest}

Dr. Vieta has received grants and served as consultant, advisor or CME speaker for the following entities: AB-Biotics, Actavis, Allergan, AstraZeneca, Bristol-Myers Squibb, Ferrer, Forest Research Institute, Gedeon Richter, Glaxo-Smith-Kline, Janssen, Lundbeck, Otsuka, Pfizer, Roche, Sanofi-Aventis, Servier, Shire, Sunovion, Takeda, Telefónica, the Brain and Behaviour Foundation, the Spanish Ministry of Science and Innovation (CIBERSAM), the Seventh European Framework Programme (ENBREC), and the Stanley Medical Research Institute.

The other authors declare that they have no competing interest.

\section{Acknowledgements}

We thank all the authors of the included papers and study participants.

\section{References}

[1] Alawieh A, Zaraket FA, Li JL, Mondello S, Nokkari A, Razafsha M, et al. Systems biology, bioinformatics, and biomarkers in neuropsychiatry. Front Neurosci 2012;6:187.

[2] Domenici E, Wille DR, Tozzi F, Prokopenko I, Miller S, McKeown A, et al. Plasma protein biomarkers for depression and schizophrenia by multi analyte profiling of case-control collections. PLoS One 2010;5:e9166.

[3] Frey BN, Andreazza AC, Houenou J, Jamain S, Goldstein BI, Frye MA, et al Biomarkers in bipolar disorder: a positional paper from the International Society for Bipolar Disorders Biomarkers Task Force. Aust N Z J Psychiatry 2013;47:321-32.

[4] Cochrane handbook for systematic reviews of interventions version 5.1.0. The Cochrane Collaboration; 2011.

[5] Fernandes BS, Gama CS, Cereser KM, Yatham LN, Fries GR, Colpo G, et al. Brainderived neurotrophic factor as a state-marker of mood episodes in bipolar disorders: a systematic review and meta-regression analysis. J Psychiatr Res 2011;45:995-1004.

[6] Fernandes BS, Berk M, Turck CW, Steiner J, Goncalves CA. Decreased peripheral brain-derived neurotrophic factor levels are a biomarker of disease activity in major psychiatric disorders: a comparative meta-analysis. Mol Psychiatry 2014;19:750-1.

[7] Fernandes BS, Molendijk ML, Kohler CA, Soares JC, Leite CM, Machado-Vieira $\mathrm{R}$, et al. Peripheral brain-derived neurotrophic factor (BDNF) as a biomarker in bipolar disorder: a meta-analysis of 52 studies. BMC Med 2015;13:289.

[8] Fernandes BS, Steiner J, Berk M, Molendijk ML, Gonzalez-Pinto A, Turck CW et al. Peripheral brain-derived neurotrophic factor in schizophrenia and the role of antipsychotics: meta-analysis and implications. Mol Psychiatry 2015;20:1108-19. 
[9] Molendijk ML, Spinhoven P, Polak M, Bus BA, Penninx BW, Elzinga BM, et al. concentrations as peripheral manifestations of depression: evidence from a systematic review and meta-analyses on 179 associations $(\mathrm{N}=9484)$. Mol Psychiatry 2014;19:791-800.

[10] Fernandes BS, Steiner J, Bernstein HG, Dodd S, Pasco JA, Dean OM, et al. Creactive protein is increased in schizophrenia but is not altered by antipsychotics: meta-analysis and implications. Mol Psychiatry 2016;21:554-64.

[11] Howren MB, Lamkin DM, Suls J. Associations of depression with C-reactive protein, IL-1, and IL-6: a meta-analysis. Psychosom Med 2009:71:171-86.

[12] Fernandes BS, Steiner J, Molendijk ML, Dodd S, Nardin P, Goncalves CA, et al. C-reactive protein concentrations across the mood spectrum in bipolar disorder: a systematic review and meta-analysis. Lancet Psychiatry 2016;3(12):1147-56.

[13] Ghanizadeh A, Singh AB, Berk M, Torabi-Nami M. Homocysteine as a potential biomarker in bipolar disorders: a critical review and suggestions for improved studies. Expert Opin Ther Targets 2015;19:927-39.

[14] Cosar A, Ipcioglu OM, Ozcan O, Gultepe M. Folate and homocysteine metabolisms and their roles in the biochemical basis of neuropsychiatry. Turk J Med Sci 2014;44:1-9.

[15] Yadav U, Kumar P, Gupta S, Rai V. Role of MTHFR C677T gene polymorphism in the susceptibility of schizophrenia: an updated meta-analysis. Asian J Psychiatr 2016;20:41-51.

[16] Numata S, Kinoshita M, Tajima A, Nishi A, Imoto I, Ohmori T. Evaluation of an association between plasma total homocysteine and schizophrenia by a Mendelian randomization analysis. BMC Med Genet 2015;16:54.

[17] Muntjewerff JW, Kahn RS, Blom HJ, den Heijer M. Homocysteine, methylenetetrahydrofolate reductase and risk of schizophrenia: a meta-analysis. Mol Psychiatry 2006;11:143-9.

[18] Assies J, Mocking RJ, Lok A, Ruhe HG, Pouwer F, Schene AH. Effects of oxidative stress on fatty acid- and one-carbon-metabolism in psychiatric and cardiovascular disease comorbidity. Acta Psychiatr Scand 2014;130:163-80.

[19] Moustafa AA, Hewedi DH, Eissa AM, Frydecka D, Misiak B. Homocysteine levels in schizophrenia and affective disorders-focus on cognition. Front Behav Neurosci 2014;8:343.

[20] Baek JH, Bernstein EE, Nierenberg AA. One-carbon metabolism and bipolar disorder. Z J Psychiatry 2013;47:1013-8.

[21] Hooshmand B, Mangialasche F, Kalpouzos G, Solomon A, Kareholt I, Smith AD, et al. Association of vitamin B12, folate, and sulfur amino acids with brain magnetic resonance imaging measures in older adults: a longitudinal population-based study. JAMA Psychiatry 2016;73:606-13.

[22] Kolling J, Scherer EB, Siebert C, Longoni A, Loureiro S, Weis S, et al. Severe hyperhomocysteinemia decreases respiratory enzyme and $\mathrm{Na}(+)-\mathrm{K}(+)$ ATPase activities, and leads to mitochondrial alterations in rat amygdala. Neurotox Res 2016;29:408-18.

[23] Das UN. Folic acid and polyunsaturated fatty acids improve cognitive function and prevent depression dementia, and Alzheimer's disease - but how and why? Prostaglandins Leukot Essent Fatty Acids 2008;78:11-9.

[24] Hu H, Wang C, Jin Y, Meng Q, Liu Q, Liu K, et al. Alpha-lipoic acid defends homocysteine-induced endoplasmic reticulum and oxidative stress in HAECs. Biomed Pharmacother 2016;80:63-72.

[25] Wang G, Siow YL, Karmin O. Homocysteine stimulates nuclear factor kappaB activity and monocyte chemoattractant protein-1 expression in vascular smooth-muscle cells: a possible role for protein kinase C. Biochem J 2000;352(Pt 3):817-26.

[26] Boldyrev A, Bryushkova E, Mashkina A, Vladychenskaya E. Why is homocysteine toxic for the nervous and immune systems? Curr Aging Sci 2013;6:2936.

[27] Skovierova H, Mahmood S, Blahovcova E, Hatok J, Lehotsky J, Murin R. Effect of homocysteine on survival of human glial cells. Physiol Res 2015;64:74754.

[28] Kim BJ, Seo M, Huh JK, Kwon CH, Kim JT, Sung KC, et al. Associations of plasma homocysteine levels with arterial stiffness in prehypertensive individuals. Clin Exp Hypertens 2011;33:411-7.

[29] Kinoshita M, Numata S, Tajima A, Shimodera S, Imoto I, Ohmori T. Plasma total homocysteine is associated with DNA methylation in patients with schizophrenia. Epigenetics 2013;8:584-90.

[30] Kok DE, Dhonukshe-Rutten RA, Lute C, Heil SG, Uitterlinden AG, van der Velde $\mathrm{N}$, et al. The effects of long-term daily folic acid and vitamin B12 supplementation on genome-wide DNA methylation in elderly subjects. Clin Epigenetics 2015; 7:121.

[31] Pana A. Homocysteine and neuropsychiatric disease. Psychiatr Ann 2015:45:463-8

[32] Berk M, Kapczinski F, Andreazza AC, Dean OM, Giorlando F, Maes M, et al. Pathways underlying neuroprogression in bipolar disorder: focus on inflammation, oxidative stress and neurotrophic factors. Neurosci Biobehav Rev 2011;35:804-17.

[33] Sharma AN, Bauer IE, Sanches M, Galvez JF, Zunta-Soares GB, Quevedo J, et al. Common biological mechanisms between bipolar disorder and type 2 diabetes: focus on inflammation. Prog Neuropsychopharmacol Biol Psychiatry 2014;54:289-98.

[34] Peng HY, Man CF, Xu J, Fan Y. Elevated homocysteine levels and risk of cardiovascular and all-cause mortality: a meta-analysis of prospective studies. J Zhejiang Univ Sci B 2015;16:78-86.

[35] Nazef K, Khelil M, Chelouti H, Kacimi G, Bendini M, Tazir M, et al. Hyperhomocysteinemia is a risk factor for Alzheimer's disease in an Algerian population. Arch Med Res 2014;45:247-50.
[36] Beydoun MA, Beydoun HA, Gamaldo AA, Teel A, Zonderman AB, Wang Y. Epidemiologic studies of modifiable factors associated with cognition and dementia: systematic review and meta-analysis. BMC Public Health 2014; $14: 643$.

[37] Nabi H, Bochud M, Glaus J, Lasserre AM, Waeber G, Vollenweider P, et al Association of serum homocysteine with major depressive disorder: results from a large population-based study. Psychoneuroendocrinology 2013;38:2309-18.

[38] Reif A, Pfuhlmann B, Lesch KP. Homocysteinemia as well as methylenetetrahydrofolate reductase polymorphism are associated with affective psychoses. Prog Neuropsychopharmacol Biol Psychiatry 2005;29:1162-8.

[39] Bjelland I, Tell GS, Vollset SE, Refsum H, Ueland PM. Folate, vitamin B12, homocysteine, and the MTHFR $677 \mathrm{C}->\mathrm{T}$ polymorphism in anxiety and depression: the Hordaland Homocysteine Study. Arch Gen Psychiatry 2003;60:618-26.

[40] Gu P, DeFina LF, Leonard D, John S, Weiner MF, Brown ES. Relationship between serum homocysteine levels and depressive symptoms: the Cooper Center Longitudinal Study. J Clin Psychiatry 2012;73:691-5.

[41] Delport D, Schoeman R, van der Merwe N, van der Merwe L, Fisher LR, Geiger $\mathrm{D}$, et al. Significance of dietary folate intake, homocysteine levels and MTHFR $677 \mathrm{C}>\mathrm{T}$ genotyping in South African patients diagnosed with depression: test development for clinical application. Metab Brain Dis 2014;29:377-84.

[42] Bala KA, Dogan M, Mutluer T, Kaba S, Aslan O, Balahoroglu R, et al. Plasma amino acid profile in autism spectrum disorder (ASD). Eur Rev Med Pharmacol Sci 2016;20:923-9.

[43] Nishi A, Numata S, Tajima A, Kinoshita M, Kikuchi K, Shimodera S, et al. Metaanalyses of blood homocysteine levels for gender and genetic association studies of the MTHFR C677T polymorphism in schizophrenia. Schizophr Bull 2014;40:1154-63.

[44] Dias VV, Brissos S, Cardoso C, Andreazza AC, Kapczinski F. Serum homocysteine levels and cognitive functioning in euthymic bipolar patients. J Affect Disord 2009;113:285-90.

[45] Bortolato B, Miskowiak KW, Kohler CA, Maes M, Fernandes BS, Berk M, et al. Cognitive remission: a novel objective for the treatment of major depression? BMC Med 2016;14:9.

[46] Vuksan-Cusa B, Jakovljevic M, Sagud M, Mihaljevic Peles A, Marcinko D, Topic $\mathrm{R}$, et al. Metabolic syndrome and serum homocysteine in patients with bipolar disorder and schizophrenia treated with second generation antipsychotics. Psychiatry Res 2011;189:21-5.

[47] Ghanizadeh A. Increased glutamate and homocysteine and decreased glutamine levels in autism: a review and strategies for future studies of amino acids in autism. Dis Markers 2013;35:281-6.

[48] Higgins JP, Thompson SG, Deeks JJ, Altman DG. Measuring inconsistency in meta-analyses. BMJ 2003;327:557-60.

[49] Stang A. Critical evaluation of the Newcastle-Ottawa scale for the assessment of the quality of nonrandomized studies in meta-analyses. Eur J Epidemiol 2010;25:603-5

[50] Handbook for Systematic reviews of Interventions Version 5.1.0. Higgins JPT, Green S (Editors). The Cochrane Collaboration 2011. Available from www.cochrane-handbook.org. [updated March 2011].

[51] Sistrom CL, Mergo PJ. A simple method for obtaining original data from published graphs and plots. AJR Am J Roentgenol 2000;174:1241-4.

[52] Hamilton M. A rating scale for depression. J Neurol Neurosurg Psychiatry 1960;23:56-62.

[53] Young RC, Biggs JT, Ziegler VE, Meyer DA. A rating scale for mania: reliability, validity and sensitivity. Br J Psychiatry 1978;133:429-35.

[54] Carvalho AF, Kohler CA, Brunoni AR, Miskowiak KW, Herrmann N, Lanctot KL, et al. Bias in peripheral depression biomarkers. Psychother Psychosom 2016;85:81-90

[55] Carvalho AF, Kohler CA, Fernandes BS, Quevedo J, Miskowiak KW, Brunoni AR, et al. Bias in emerging biomarkers for bipolar disorder. Psychol Med 2016;46:2287-97.

[56] Egger M, Davey Smith G, Schneider M, Minder C. Bias in meta-analysis detected by a simple, graphical test. BMJ 1997;315:629-34

[57] Duval S, Tweedie R. Trim and fill: a simple funnel-plot-based method of testing and adjusting for publication bias in meta-analysis. Biometrics 2000;56:455-63.

[58] Cohen J. Statistical power analysis for the behavioral sciences, 2nd ed., NJ: Lawrence Erlbaum Associates, Inc.; 1988.

[59] Lau J, Ioannidis JP, Schmid CH. Quantitative synthesis in systematic reviews. Ann Intern Med 1997;127:820-6.

[60] Vargas HO, Nunes SO, Barbosa DS, Vargas MM, Cestari A, Dodd S, et al. Castelli risk indexes 1 and 2 are higher in major depression but other characteristics of the metabolic syndrome are not specific to mood disorders. Life Sci 2014;102:65-71.

[61] Dittmann S, Seemuller F, Schwarz MJ, Kleindienst N, Stampfer R, Zach J, et al Association of cognitive deficits with elevated homocysteine levels in euthymic bipolar patients and its impact on psychosocial functioning: preliminary results. Bipolar Disord 2007:9:63-70.

[62] Levine J, Sela BA, Osher Y, Belmaker RH. High homocysteine serum levels in young male schizophrenia and bipolar patients and in an animal model. Prog Neuropsychopharmacol Biol Psychiatry 2005;29:1181-91.

[63] Bell IR, Morrow FD, Read M, Berkes S, Perrone G. Low thyroxine levels in female psychiatric inpatients with riboflavin deficiency: implications for folate-dependent methylation. Acta Psychiatr Scand 1992;85:360-3. 
[64] Carney MW, Chary TK, Laundy M, Bottiglieri T, Chanarin I, Reynolds EH, et al. Red cell folate concentrations in psychiatric patients. J Affect Disord 1990;19:207-13.

[65] Carney MW, Sheffield BF. Serum folic acid and B12 in 272 psychiatric inpatients. Psychol Med 1978;8:139-44.

[66] Coppen A, Abou-Saleh MT. Plasma folate and affective morbidity during longterm lithium therapy. Br J Psychiatry 1982;141:87-9.

[67] Davison KM, Kaplan BJ. Vitamin and mineral intakes in adults with mood disorders: comparisons to nutrition standards and associations with sociodemographic and clinical variables. J Am Coll Nutr 2011;30:547-58.

[68] Ellingrod VL, Taylor SF, Dalack G, Grove TB, Bly MJ, Brook RD, et al. Risk factors associated with metabolic syndrome in bipolar and schizophrenia subjects treated with antipsychotics: the role of folate pharmacogenetics. J Clin Psychopharmacol 2012;32:261-5.

[69] Issac TG, Soundarya S, Christopher R, Chandra SR. Vitamin B12 deficiency: an important reversible co-morbidity in neuropsychiatric manifestations. Indian J Psychol Med 2015;37:26-9.

[70] Lee S, Chow CC, Shek CC, Wing YK, Chen CN. Folate concentration in Chinese psychiatric outpatients on long-term lithium treatment. J Affect Disord 1992;24:265-70.

[71] Lundin NB, Niciu MJ, Luckenbaugh DA, Ionescu DF, Richards EM, Vande Voort $\mathrm{JL}$, et al. Baseline vitamin B12 and folate levels do not predict improvement in depression after a single infusion of ketamine. Pharmacopsychiatry 2014;47:141-4.

[72] McKeon P, Shelley R, O’Regan S, O’Broin J. Serum and red cell folate and affective morbidity in lithium prophylaxis. Acta Psychiatr Scand 1991;83:199-201.

[73] McLaughlin B, McMahon A. Folate and depression. Br J Psychiatry 1993;162:572.

[74] Permoda-Osip A, Dorszewska J, Bartkowska-Sniatkowska A, Chlopocka-Wozniak M, Rybakowski JK. Vitamin B12 level may be related to the efficacy of single ketamine infusion in bipolar depression. Pharmacopsychiatry 2013;46:227-8.

[75] Permoda-Osip A, Dorszewska J, Skibinska M, Chlopocka-Wozniak M, Rybakowski JK. Hyperhomocysteinemia in bipolar depression: clinical and biochemical correlates. Neuropsychobiology 2013;68:193-6.

[76] Silver H. Vitamin B12 levels are low in hospitalized psychiatric patients. Isr J Psychiatry Relat Sci 2000;37:41-5.

[77] Snaith RP, Mehta S, Raby AH. Serum folate and vitamin B12 in epileptics with and without mental illness. Br J Psychiatry 1970;116:179-83.

[78] Stern SL, Brandt JT, Hurley RS, Stagno SJ, Stern MG, Smeltzer DJ. Serum and red cell folate concentrations in outpatients receiving lithium carbonate. Int Clin Psychopharmacol 1988;3:49-52.

[79] Alexopoulos P, Topalidis S, Irmisch G, Prehn K, Jung SU, Poppe K, et al. Homocysteine and cognitive function in geriatric depression. Neuropsychobiology 2010;61:97-104.

[80] Gultepe M, Ozcan O, Avsar K, Cetin M, Ozdemir AS, Gok M. Urine methylmalonic acid measurements for the assessment of cobalamin deficiency related to neuropsychiatric disorders. Clin Biochem 2003;36:275-82.

[81] Henderson JG, Dawson AA. Serum vitamin-B12 levels in psychiatric patients on long-term psychotropic drug therapy. Br J Psychiatry 1970;116:439-42.

[82] Iosifescu DV, Papakostas GI, Lyoo IK, Lee HK, Renshaw PF, Alpert JE, et al. Brain MRI white matter hyperintensities and one-carbon cycle metabolism in nongeriatric outpatients with major depressive disorder (Part I). Psychiatry Res 2005;140:291-9.

[83] Ipcioglu OM, Ozcan O, Gultepe M, Ates A, Basoglu C, Cakir E. Reduced urinary excretion of homocysteine could be the reason of elevated plasma homocysteine in patients with psychiatric illnesses. Clin Biochem 2008:41:831-5.

[84] Kaner G, Soylu M, Yuksel N, Inanc N, Ongan D, Basmisirli E. Evaluation of nutritional status of patients with depression. Biomed Res Int 2015;2015:521481.

[85] Lok A, Mocking RJ, Assies J, Koeter MW, Bockting CL, de Vries GJ, et al. The onecarbon-cycle and methylenetetrahydrofolate reductase (MTHFR) C677T polymorphism in recurrent major depressive disorder; influence of antidepressant use and depressive state? J Affect Disord 2014;166:115-23.

[86] Mischoulon D, Lamon-Fava S, Selhub J, Katz J, Papakostas GI, Iosifescu DV, et al. Prevalence of MTHFR C677T and MS A2756G polymorphisms in major depressive disorder, and their impact on response to fluoxetine treatment. CNS Spectr 2012;17:76-86

[87] Narayan SK, Verman A, Kattimani S, Ananthanarayanan PH, Adithan C. Plasma homocysteine levels in depression and schizophrenia in South Indian Tamilian population. Indian J Psychiatry 2014;56:46-53.

[88] Scott TM, Tucker KL, Bhadelia A, Benjamin B, Patz S, Bhadelia R, et al. Homocysteine and B vitamins relate to brain volume and white-matter changes in geriatric patients with psychiatric disorders. Am J Geriatr Psychiatry 2004;12:631-8.

[89] Wolfersdorf M, Maier V, Froscher W, Laage M, Straub R. [Folic acid deficiency in patients hospitalized with depression? A pilot study of clinical relevance] Nervenarzt 1993;64:269-72.

[90] Hasanah CI, Khan UA, Musalmah M, Razali SM. Reduced red-cell folate in mania. J Affect Disord 1997;46:95-9.

[91] Chen Z, Liu Y, Zhang D, Liu Z, Wang P, Zhou D, et al. C677T methylenetetrahydrofolate reductase gene polymorphisms in bipolar disorder: an association study in the Chinese population and a meta-analysis of genetic association studies. Neurosci Lett 2009;449:48-51.
[92] Jonsson EG, Larsson K, Vares M, Hansen T, Wang AG, Djurovic S, et al. Two methylenetetrahydrofolate reductase gene (MTHFR) polymorphisms, schizophrenia and bipolar disorder: an association study. Am J Med Genet B Neuropsychiatr Genet 2008;147B:976-82.

[93] Kempisty B, Bober A, Luczak M, Czerski P, Szczepankiewicz A, Hauser J, et al. Distribution of $1298 \mathrm{~A}>\mathrm{C}$ polymorphism of methylenetetrahydrofolate reductase gene in patients with bipolar disorder and schizophrenia. Eur Psychiatry 2007;22:39-43.

[94] Kempisty B, Mostowska A, Gorska I, Luczak M, Czerski P, Szczepankiewicz A, et al. Association of $677 \mathrm{C}>\mathrm{T}$ polymorphism of methylenetetrahydrofolate reductase (MTHFR) gene with bipolar disorder and schizophrenia. Neurosci Lett 2006;400:267-71.

[95] Kempisty B, Sikora J, Lianeri M, Szczepankiewicz A, Czerski P, Hauser J, et al. MTHFD 1958G $>$ A and MTR 2756A $>$ G polymorphisms are associated with bipolar disorder and schizophrenia. Psychiatr Genet 2007;17:177-81.

[96] Malhotra N, Kulhara P, Chakrabarti S, Grover S. A prospective, longitudinal study of metabolic syndrome in patients with bipolar disorder and schizophrenia. J Affect Disord 2013;150:653-8.

[97] Arinami T, Yamada N, Yamakawa-Kobayashi K, Hamaguchi H, Toru M. Methylenetetrahydrofolate reductase variant schizophrenia/depression. Am J Med Genet 1997;74:526-8.

[98] Davison KM, Kaplan BJ. Nutrient intakes are correlated with overall psychiatric functioning in adults with mood disorders. Can J Psychiatry 2012;57:85-92.

[99] Hickie I, Scott E, Naismith S, Ward PB, Turner K, Parker G, et al. Late-onset depression: genetic, vascular and clinical contributions. Psychol Med 2001;31:1403-12.

[100] Kunugi H, Fukuda R, Hattori M, Kato T, Tatsumi M, Sakai T, et al. C677T polymorphism in methylenetetrahydrofolate reductase gene and psychoses. Mol Psychiatry 1998;3:435-7.

[101] Tan EC, Chong SA, Lim LC, Chan AO, Teo YY, Tan CH, et al. Genetic analysis of the thermolabile methylenetetrahydrofolate reductase variant in schizophrenia and mood disorders. Psychiatr Genet 2004;14:227-31.

[102] Callaghan N, Mitchell R, Cotter P. The relationship of serum folic acid and vitamin B 12 levels to psychosis in epilepsy. Ir J Med Sci 1969;8:497-505.

[103] Coppen A, Swade C, Jones SA, Armstrong RA, Blair JA, Leeming RJ. Depression and tetrahydrobiopterin: the folate connection. J Affect Disord 1989;16:1037.

[104] Ezzaher A, Mouhamed DH, Mechri A, Omezzine A, Neffati F, Douki W, et al. Hyperhomocysteinemia in Tunisian bipolar I patients. Psychiatry Clin Neurosci 2011;65:664-71.

[105] Ozbek Z, Kucukali CI, Ozkok E, Orhan N, Aydin M, Kilic G, et al. Effect of the methylenetetrahydrofolate reductase gene polymorphisms on homocysteine, folate and vitamin B12 in patients with bipolar disorder and relatives. Prog Neuropsychopharmacol Biol Psychiatry 2008;32:1331-7.

[106] Chiarani F, Tramontina JF, Cereser KM, Kunz M, Paim L, Vargas CR, et al. Homocysteine and other markers of cardiovascular risk during a manic episode in patients with bipolar disorder. Rev Bras Psiquiatr 2013;35:157-60.

[107] Bromberg A, Bersudsky Y, Levine J, Agam G. Global leukocyte DNA methylation is not altered in euthymic bipolar patients. J Affect Disord 2009;118:234-9.

[108] Vuksan-Cusa B, Sagud M, Jakovljevic M, Peles AM, Jaksic N, Mihaljevic S, et al. Association between C-reactive protein and homocysteine with the subcomponents of metabolic syndrome in stable patients with bipolar disorder and schizophrenia. Nord J Psychiatry 2013;67:320-5.

[109] Osher Y, Bersudsky Y, Silver H, Sela BA, Belmaker RH. Neuropsychological correlates of homocysteine levels in euthymic bipolar patients. J Affect Disord 2008;105:229-33.

[110] Osher Y, Sela BA, Levine J, Belmaker RH. Elevated homocysteine levels in euthymic bipolar disorder patients showing functional deterioration. Bipolar Disord 2004;6:82-6.

[111] Doganavsargil Baysal GO, Gokmen Z, Akbas H, Cinemre B, Metin O, Karaman T. [Association of serum homocysteine and methionine levels with cognition and functioning in bipolar disorder]. Turk Psikiyatri Derg 2013;24:7-16.

[112] Dittmann S, Seemuller F, Grunze HC, Schwarz MJ, Zach J, Fast K, et al. The impact of homocysteine levels on cognition in euthymic bipolar patients: a cross-sectional study. J Clin Psychiatry 2008;69:899-906.

[113] Puig-Alcaraz C, Fuentes-Albero M, Calderon J, Garrote D, Cauli O. Increased homocysteine levels correlate with the communication deficit in children with autism spectrum disorder. Psychiatry Res 2015;229:1031-7.

[114] Ganguly P, Alam SF. Role of homocysteine in the development of cardiovascular disease. Nutr J 2015;14:6.

[115] Jadavji NM, Wieske F, Dirnagl U, Winter C. Methylenetetrahydrofolate reductase deficiency alters levels of glutamate and gamma-aminobutyric acid in brain tissue. Mol Genet Metab Rep 2015;3:1-4.

[116] Yang Z, Wang L, Zhang W, Wang X, Zhou S. Plasma homocysteine involved in methylation and expression of thrombomodulin in cerebral infarction. Biochem Biophys Res Commun 2016;473:1218-22.

[117] Fernandes BS, Dash S, Jacka F, Dodd S, Carvalho AF, Kohler CA, et al. Leptin in bipolar disorder: a systematic review and meta-analysis. Eur Psychiatry 2016;35:1-7.

[118] Ludwig B, Dwivedi Y. Dissecting bipolar disorder complexity through epigenomic approach. Mol Psychiatry 2016;21:1490-8.

[119] Mitchell ES, Conus N, Kaput J. B vitamin polymorphisms and behavior: evidence of associations with neurodevelopment, depression, schizophrenia, 
bipolar disorder and cognitive decline. Neurosci Biobehav Rev 2014;47:30720.

[120] Durga J, van Boxtel MP, Schouten EG, Bots ML, Kok FJ, Verhoef P. Folate and the methylenetetrahydrofolate reductase $677 \mathrm{C}->\mathrm{T}$ mutation correlate with cognitive performance. Neurobiol Aging 2006;27:334-43.

[121] Schiepers OJ, van Boxtel MP, de Groot RH, Jolles J, Bekers O, Kok FJ, et al. Genetic variation in folate metabolism is not associated with cognitive functioning or mood in healthy adults. Prog Neuropsychopharmacol Biol Psychiatry 2011;35:1682-8.

[122] Yeh TK, Hu CY, Yeh TC, Lin PJ, Wu CH, Lee PL, et al. Association of polymorphisms in BDNF, MTHFR, and genes involved in the dopaminergic pathway with memory in a healthy Chinese population. Brain Cogn 2012;80: 282-9.

[123] Eszlari N, Kovacs D, Petschner P, Pap D, Gonda X, Elliott R, et al. Distinct effects of folate pathway genes MTHFR and MTHFD1L on ruminative response style: a potential risk mechanism for depression. Transl Psychiatry 2016;6:e745.

[124] Pirchl M, Ullrich C, Humpel C. Differential effects of short- and long-term hyperhomocysteinaemia on cholinergic neurons, spatial memory and microbleedings in vivo in rats. Eur J Neurosci 2010;32:1516-27.

[125] Martinez-Aran A, Vieta E. Cognition as a target in schizophrenia, bipolar disorder and depression. Eur Neuropsychopharmacol 2015;25:151-7.

[126] Miskowiak KW, Carvalho AF, Vieta E, Kessing LV. Cognitive enhancement treatments for bipolar disorder: a systematic review and methodological recommendations. Eur Neuropsychopharmacol 2016;26:1541-61.

[127] Vieta E, Torrent C. Functional remediation: the pathway from remission to recovery in bipolar disorder. World Psychiatry 2016;15:288-9.

[128] Sharpley AL, Hockney R, McPeake L, Geddes JR, Cowen PJ. Folic acid supplementation for prevention of mood disorders in young people at familial risk: a randomised, double blind, placebo controlled trial. J Affect Disord 2014; $167: 306-11$

[129] Bedson E, Bell D, Carr D, Carter B, Hughes D, Jorgensen A, et al. Folate Augmentation of Treatment - Evaluation for Depression (FolATED): randomised trial and economic evaluation. Health Technol Assess 2014;18:vii-i [1159].

[130] Almeida OP, Ford AH, Flicker L. Systematic review and meta-analysis of randomized placebo-controlled trials of folate and vitamin B12 for depression. Int Psychogeriatr 2015;27:727-37.

[131] Wu D, Pardridge WM. Blood-brain barrier transport of reduced folic acid Pharm Res 1999;16:415-9.

[132] Pietrzik K, Bailey L, Shane B. Folic acid and L-5-methyltetrahydrofolate: comparison of clinical pharmacokinetics and pharmacodynamics. Clin Pharmacokinet 2010;49:535-48.

[133] Geddes JR, Gardiner A, Rendell J, Voysey M, Tunbridge E, Hinds C, et al. Comparative evaluation of quetiapine plus lamotrigine combination versus quetiapine monotherapy (and folic acid versus placebo) in bipolar depression
(CEQUEL): a $2 \times 2$ factorial randomised trial. Lancet Psychiatry 2016;3: 31-9.

[134] Dankner R, Chetrit A, Dror GK, Sela BA. Physical activity is inversely associated with total homocysteine levels, independent of C677T MTHFR genotype and plasma B vitamins. Age 2007;29:219-27.

[135] Vancampfort D, Firth J, Schuch F, Rosenbaum S, De Hert M, Mugisha J, et al. Physical activity and sedentary behavior in people with bipolar disorder: a systematic review and meta-analysis. J Affect Disord 2016;201:145-52.

[136] Deminice R, Ribeiro DF, Frajacomo FTT. The effects of acute exercise and exercise training on plasma homocysteine: a meta-analysis. PLoS ONE 2016;11(3):e0151653. http://dx.doi.org/10.1371/journal.pone.0151653.

[137] Vancampfort D, Stubbs B. Physical activity and metabolic disease among people with affective disorders: prevention, management and implementation. J Affect Disord 2016;201:145-52.

[138] Maron BA, Loscalzo J. The treatment of hyperhomocysteinemia. Annu Rev Med 2009:60:39-54

[139] Misiak B, Frydecka D, Slezak R, Piotrowski P, Kiejna A. Elevated homocysteine level in first-episode schizophrenia patients - the relevance of family history of schizophrenia and lifetime diagnosis of cannabis abuse. Metab Brain Dis 2014;29:661-70.

[140] Gaikwad NW. Mass spectrometry evidence for formation of estrogen-homocysteine conjugates: estrogens can regulate homocysteine levels. Free Radic Biol Med 2013;65:1447-54.

[141] Slyepchenko A, Maes M, Jacka FN, Kohler CA, Barichello T, McIntyre RS, et al. Gut microbiota, bacterial translocation, and interactions with diet: pathophysiological links between major depressive disorder and non-communicable medical comorbidities. Psychother Psychosom 2016;86:31-46.

[142] LeBlanc JG, Laino JE, del Valle MJ, Vannini V, van Sinderen D, Taranto MP, et al. B-group vitamin production by lactic acid bacteria - current knowledge and potential applications. J Appl Microbiol 2011;111:1297-309.

[143] Rogers GB, Keating DJ, Young RL, Wong ML, Licinio J, Wesselingh S. From gut dysbiosis to altered brain function and mental illness: mechanisms and pathways. Mol Psychiatry 2016;21:738-48.

[144] Dinan TG, Cryan JF. Melancholic microbes: a link between gut microbiota and depression? Neurogastroenterol Motil 2013;25:713-9.

[145] Selhub J. Homocysteine metabolism. Annu Rev Nutr 1999;19:217-46.

[146] Obeid R, Herrmann W. Mechanisms of homocysteine neurotoxicity in neurodegenerative diseases with special reference to dementia. FEBS Lett 2006;580:2994-3000.

[147] Young JJ, Silber T, Bruno D, Galatzer-Levy IR, Pomara N, Marmar CR. Is there progress? An overview of selecting biomarker candidates for major depressive disorder. Front Psychiatry 2016;7:72.

[148] Fernandes BS, Gama CS, Kauer-Sant'Anna M, Lobato MI, Belmonte-de-Abreu P, Kapczinski F. Serum brain-derived neurotrophic factor in bipolar and unipolar depression: a potential adjunctive tool for differential diagnosis. J Psychiatr Res 2009;43:1200-4. 